\title{
QUO VADIS VILLAGE FINANCIAL MANAGEMENT: TRANSPARENCY VS ACCOUNTABILITY (CASE STUDY IN BOGOR DISTRICT)
}

\author{
Rochman Marota*)1, Agung Fajar Ilmiyono*), and Indah Setiarini Erganda*)
}

${ }^{*}$ Economic and Business Faculty, University of Pakuan

Jl. Pakuan, RT. 02/ RW. 06, Tegallega, Bogor, Indonesia 16129

\begin{abstract}
Villages obtain their sources of income from original village income, transfers, and other income. Considerable income makes the village government demand to increase transparency and accountability along with the development of public sector accounting. However, transparency and accountability are still a problem for some villages. This study aimed to determine the effect of transparency and accountability on the financial management in 13 villages in Sukaraja District, Bogor Regency. The data were collected using a questionnaire distributed to 83 respondents, selected using the purposive sampling method. The data analysis methods included a validity test, reliability test, t-test, f-test, coefficient of determination test, multiple linear regression, normality test, heteroscedasticity test, and descriptive statistics. Partial testing with t-test showed that transparency had no significant effect on village financial management because some respondents answered that they disagreed. Therefore, it can be concluded that transparency had been implemented but not yet maximized. While accountability partially had a significant effect on village financial management, accountability had run well. Based on the simultaneous testing results with the f-test, transparency and accountability simultaneously positively affected village financial management.
\end{abstract}

Keywords: village financial management, village government, transparency, accountability, multiple linear regression

\begin{abstract}
Abstrak: Desa mendapatkan sumber daya pendapatan dari pendapatan asli desa, transfer, dan pendapatan lain-lain. Pendapatan yang cukup banyak membuat pemerintah desa dituntut untuk meningkatkan transparansi dan pertanggungjawaban seiring dengan perkembangan akuntansi sektor publik. Namun transparansi dan akuntabilitas masih menjadi masalah bagi beberapa desa. Tujuan penelitian ini yaitu untuk mengetahui pengaruh transparansi dan akuntabilitas terhadap pengelolaan keuangan desa studi pada 13 desa di Kecamatan Sukaraja, Kabupaten Bogor. Metode pengumpulan data menggunakan kuesioner sebanyak 83 responden, dipilih menggunakan metode purposive sampling. Metode analisis data uji validitas, uji reliabilitas, uji t, uji f, uji koefisien determinasi, regresi linier berganda, uji normalitas, uji heteroskedastisitas, dan statistik deskriptif. Pengujian secara parsial dengan uji t mendapatkan hasil transparansi tidak berpengaruh signifikan terhadap pengelolaan keuangan desa. Hal ini karena beberapa responden menjawab kurang setuju, sehingga dapat disimpulkan transparansi telah terlaksana namun belum maksimal. Akuntabilitas secara parsial berpengaruh signifikan terhadap pengelolaan keuangan desa, sehingga akuntabilitas telah berjalan dengan baik. Hasil pengujian secara simultan dengan uji $F$ yaitu transparansi dan akuntabilitas secara simultan berpengaruh positif terhadap pengelolaan keuangan desa.
\end{abstract}

Kata kunci: pengelolaan keuangan desa, pemerintah desa, transparansi, akuntabilitas, regresi linear berganda

\footnotetext{
${ }^{1}$ Corresponding author:

Email: rochman.marota@unpak.ac.id
} 


\section{INTRODUCTION}

Indonesia is dominated by a total of 75,436 villages. Village is a government unit that is directly related to the village community. According to Article 1 of Law Number 6 Year 2014, it is stated that the village is a legal community unit that has territorial boundaries that are authorized to regulate and manage government affairs, the interests of the local community based on community initiatives, original rights, and/or traditional rights that are recognized and respected in the government system of the Unitary of Republic of Indonesia.

Villages obtain sources of income from local revenues, transfers, and other income sources. Based on the considerable amounts of revenues, Ministry of Internal Affair Regulation No. 20 of 2018 concerning Village Financial Management was issued so that village financial management is structured, directed, and well managed in accordance with the principles of transparency and accountability. Village financial management is all village rights and obligations that can be valued in the form of money for all activities including planning, implementing, administering, reporting, and village financial accountability.

According to Marota and Alipudin (2019), Bogor District has 40 sub-districts and 428 villages / wards. Almost most villages in Bogor already classified as a self-help village namely 237 villages and 191 villages are villages self-sufficiency. Locally-generated revenue Bogor Regency increased by 70 percent during the period 2014 to 2018, from only Rp900 billion in 2014, reaching Rp1.56 trillion in 2018. Potential villages in Bogor District until now increasingly big when viewed from the data.

Ramadanis and Ahyaruddin (2019) in their research stated that the phenomenon that occurs in the development of the public sector in Indonesia including at the village level is the strengthening of accountability demands by the community. Meutia and Liliana (2017) in her research stated that reporting and accountability are still a problem for some villages since not all villages studied have human resources that control reporting and accountability.

Village fund management is part of public funds management which operated from high state institutions and disctricts above the village (Sujarweni, 2015).
According to Umami and Nurodin (2017), transparency functions as a provider of information on government for the public and guarantees easiness in obtaining accurate and adequate information. Hendratmi et al. (2017) concluded that transparency is a principle that guarantees access or freedom for everyone to obtain information on governance: the policy making process and its implementation, and the results achieved. Based on the above understanding, it can be concluded that transparency is the easiness in obtaining open and honest financial information on government accountability both in the managing resources and the results that have been achieved.

According to Mardiasmo (2018), public accountability is the obligation of the holders of the mandate (agents) to provide responsibility, to present, report, and disclose all activities that become his responsibility to the party providing the mandate (principal) who has the right of authority to request such accountability. Ramadanis and Ahyaruddin (2019) stated that accountability is a form of obligation for a person (leader/officer/ executive) to ensure that the duties and obligations he has carried out are in accordance with applicable regulations. Based on this understanding, it can be concluded that accountability is providing accountability for all activities carried out to ensure that the activities have been carried out in accordance with applicable regulations.

Article 1 paragraph 6 of the Minister of Home Affairs Regulation of the Republic of Indonesia Number 20 of 2018 concerning village financial management explains that village financial management is the whole activities which include planning, implementing, administering, reporting, and providing accountability of village finances. Soleh and Rochansjah (2015: 3 ) defined village finance as all village rights and obligations that can be valued in the form of money, and anything in the form of money or in the form of goods that can be owned by villages in connection with the implementation of these rights and obligations. In broad outline of this understanding, it can be concluded that village financial management is all village rights and obligations that can be valued in the form of money on all activities including planning, implementing, administering, reporting, and providing village financial accountability. According to these problems, the researchers were interested in identifying whether the villages in Bogor District have implemented village financial management properly. 


\section{METHODS}

This study used verification type of research, with the explanatory survey research method to village government in Bogor District and Sub-District. The sub-districts were consisting of 13 (thirteen) villages. The questionnaires were distributed from January to March 2020, and then the data were processed from April to June 2020.

The primary data were used in this study with the data collection technique of questionnaire, which a closed questionnaire in with statements and scores were determined by the researchers, making it easier for the respondents to choose the provided answers. The unit of analysis in this study is an individual, which means that the questionnaire is distributed to everyone who is the target of the respondents. The target respondents themselves are people who understand or are directly related to village financial management.

This study used the data from the results of the questionnaire, which had been responded by the respondents so that the testing of the data had to be carried out including the validity test to measure the extent to which the data were feasible or not feasible to be used and the reliability test to measure the level of consistency of something to be measured. Furthermore, statistical tests are carried out to determine whether there is an influence between one variable and another.

Following this, the statistical data test was performed with the classic assumption tests: normality test, multicollinearity test, heteroscedasticity test, and multiple linear regression test. Besides that, the hypothesis tests included $\mathrm{t}$ test, $\mathrm{F}$ test, determination coefficient test and descriptive statistical test. All tests are processed using SPSS 25, after the data is processed, it can be concluded that the results of these tests.

In their research, Faridah and Suryono (2015) in the Journal of Transparency and Accountability of Village Governance in the Management of the Village Budget and Expenditure (APBDes) stated that the Head of Sidogedungbatu Village, Sangkapura Subdistrict, Gresik Regency, had implemented the principles of transparency and accountability in managing the APBDes in the fiscal budget of 2013.
In addition, Umami and Nurodin (2017) in their research with a similar title in the Journal of the Effect of Transparency and Accountability on Village Financial Management stated that transparency affects the village financial management, and there is an effect of accountability on village financial management, and transparency and accountability effect simultaneously to the village financial management.

Furthermore, there was a study with a journal entitled Accountability and Transparency in the Management of the Village Budget and Expenditure (APBDesa) in 2016 stating that the result of the study indicates that the Balimbing Nagari government in Rambat District, Tanah Datar Regency has applied the principle of accountability and transparency in the management of the Village Revenue and Expenditure of Nagari.

Syafei et al. (2016) concluded that transparency has become a part of strategy to improved the performance.

Based on the description and conclusions above, the researchers constructed the following hypotheses:

$\mathrm{H}_{1}$ : Transparency has a significant effect on village financial management.

$\mathrm{H}_{2}$ : Accountability has a significant effect on village financial management.

$\mathrm{H}_{3}$ : Transparency and accountability simultaneously affect village financial management.

As illustrated in the framework above as shown in Figure 1, it can be explained that $\mathrm{H} 1$ transparency has a significant effect on village financial management, H2 accountability has a significant effect on village financial management, $\mathrm{H} 3$ transparency and accountability have a significant effect simultaneously on village financial management.

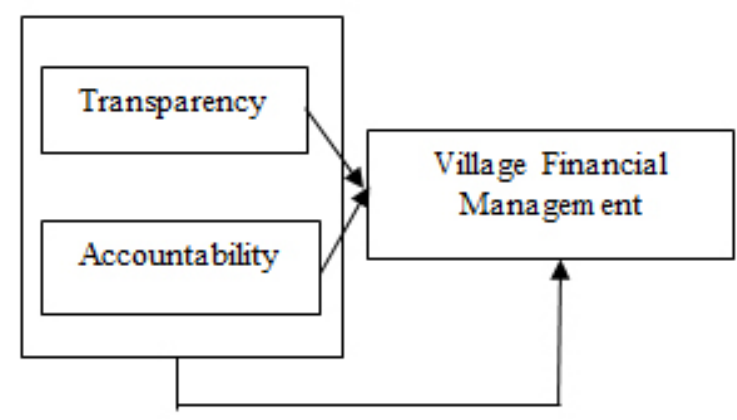

Figure 1. Research Framework 


\section{RESULTS}

The respondents in this study included the village head, village apparatus related to the village financial management, and the village council (BPD) as representatives of the community. As many as 8 sets of questionnaires were distributed to each village of: West Cilebut, East Cilebut, Pasir Jambu, Cimandala, Cijujung, Pasirlaja, Ngampar Cadas, Cikeas, Sukaraja, Cibanong, Nagrak, Gunung Geulis, Sukatani, so that as many as 104 sets of questionnaires were distributed in these villages. From the questionnaires distributed, West Cilebut, Cilebut Timur, Pasir Jambu, Cimandala, and Cijujung returned 8, 4, 7, 4 and 7 sets of questionnaires respectively. Pasirlaja, Cadas Ngampar, Cikeas, Sukaraja, and Cibanon returned $8,6,4,6$, and 7 sets of questionnaires respectively. Nagrak, Sukatani, and Gunung Geulis returned 8, 6, and 8 sets of questionnaires respectively. In total, as many as 83 sets of questionnaires were returned, and 21 sets of questionnaires that were not filled out by respondents. Before conducting the data analysis the data were tested according to the classical assumptions (Sujarweni, 2014 and Sugiyono, 2017). The classic assumption test can be tested through 2 things, namely the normality and reliability test.

Based on Figure 2, it can be concluded that the normal graph P P plot shows the points spread around the diagonal line and the distribution followed the diagonal direction; thereforem the graph shows that the data were normally distributed. In addition to knowing whether the data were normally distributed, the data were tested using the Kolmogrov-Smirnov Test as stated at Table 1.

Based on Table 1 it can be seen that the significance value is 0.066 , if the significance value is $>0.05$, the data is said to be normal. Based on those table, it can be concluded that the data were normally distributed. If the data is normally distributed, it can be continued at the next stage of testing, namely the multicollinearity test, which is shown in Table 2.

As mentioned in Table 2 that was a test whether the regression model found a correlation between the dependent variables. Based on the multicollinearity test result above, tolerance value of 0.332 and a VIF value of 3.010 indicated that 0.332 was $>0.01$, and a VIF was $3.010<10$ so that it can be concluded that the data were free from multicollinearity problem. This test could be shown as stated at Table 2.

\section{Normal P.P Plot of Regression Standardized Residual}

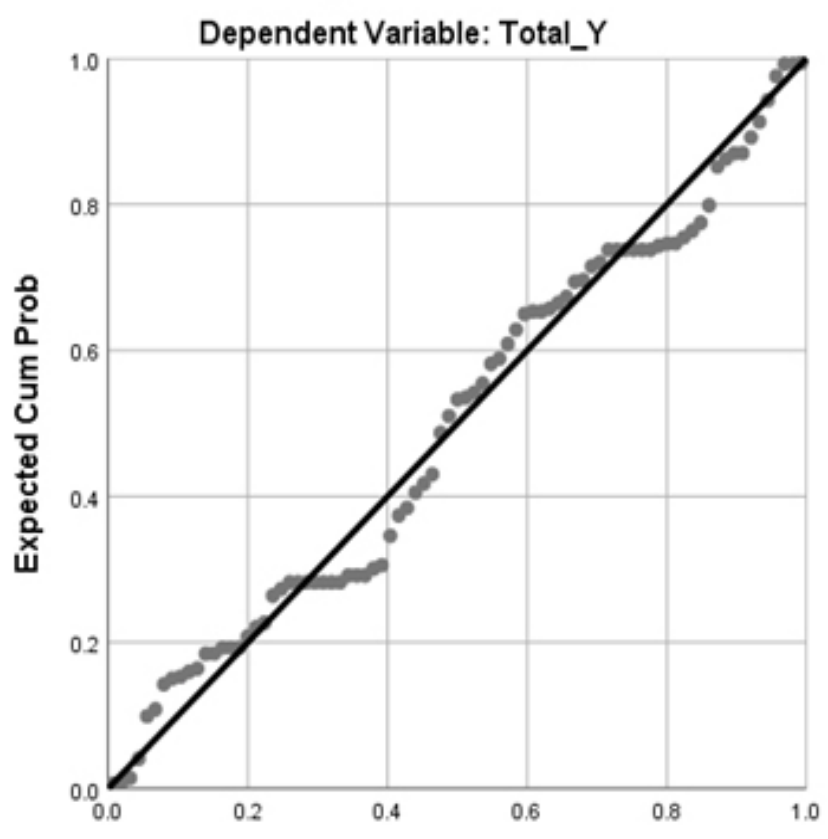

Figure 2. Normality test result

Table 1. Kolmogrov-Smirnov Test

\begin{tabular}{llc}
\hline \multicolumn{2}{c}{ One-Sample Kolmogorov-Smirnov Test } \\
\hline $\mathrm{N}$ & $\begin{array}{c}\text { Unstandardized } \\
\text { Residual }\end{array}$ \\
Normal & Mean & 83 \\
Parameters ${ }^{\mathrm{a}, \mathrm{b}}$ & Std. Deviation & .0000000 \\
Most Extreme Dif- & Absolute & .48890749 \\
ferences & Positive & .094 \\
& Negative & -.067 \\
Test Statistic & & .094 \\
Asymp. Sig. & & $.066^{\mathrm{c}}$ \\
(2-tailed) & \\
a. Test distribution is Normal; ${ }^{\mathrm{b} .}$ Calculated from data; \\
c. Lilliefors Significance Correction.
\end{tabular}

Table 2. Multicollinearity Test

\begin{tabular}{|c|c|c|}
\hline \multicolumn{3}{|c|}{ Coefficients $^{\mathrm{a}}$} \\
\hline & \multicolumn{2}{|c|}{ Collinearity Statistics } \\
\hline Model & Tolerance & VIF \\
\hline \multicolumn{3}{|l|}{ (Constant) } \\
\hline Transparency & .332 & 3.010 \\
\hline Accountability & .332 & 3.010 \\
\hline
\end{tabular}


Heteroscedasticity test shown in Table 3 , the requirement that must be met in the regression model is the absence of heteroscedasticity. From the results of the data analyses, the significance value of variable $\mathrm{X}_{1}$ was 0.232 , and $\mathrm{X}_{2}$ was 0.188 . Therefore, it can be concluded that $X_{1}$ of 0.232 was $>0.05$ and $X_{2}$ of 0.188 was $>0.05$, indicating that there was no heteroscedasticity. This test could be shown as stated at Table 3 .

As shown above, the $\mathrm{T}$ test is mentioned in Table 4 . Transparency $X_{1}$ and accountability $X_{2}$ on village financial management $(Y)$, the test result using the $t$ test. The $\mathrm{t}$ test result shows that the $\mathrm{t}$ value was $<\mathrm{t}$ table $(0.481<1.99006)$, which means $\mathrm{H}_{1}$ was rejected since transparency had no significant effect on village financial management. Furthermore, the value of (3.533 was > 1.99006), indicating that $\mathrm{H}_{2}$ was accepted since accountability affected the village financial management. After knowing the conclusion of the $t$ test, the $\mathrm{F}$ test was carried out. The result of the data analysis of the F Test to determine the effect of transparency and accountability on the village financial management simultaneously is as follows:

As shown in Table 5, the $\mathrm{F}$ test result states that $\mathrm{H} 3$ was accepted because the F count was $>$ F table (23.308> 3.109) and from this, it is also known that the significance value listed was 0,000 , which means $F$ _sig of 0,000 was $<0.05$. Based on this, transparency and accountability effectd the village financial management. It is also known from the $\mathrm{F}$ test that simultaneous transparency and accountability were also influential on the village financial management.

Furthermore, the test of the coefficient of determination shown in Table 6 is to determine the presentation of the total variation in the dependent variable on the independent variable. Based on the table, the value of R Square was 0.368 or $36.8 \%$. This result indicates that $36.8 \%$ of the variables of transparency and accountability significantly effectd the village financial management while the remaining $63.2 \%$ was affected by other variables outside the variables studied.

Based on the descriptive statistical test found in Table 7 , the descriptive statistical test aims to determine the minimum, maximum, sum, mean, and standard deviation values. From the descriptive statistical result on the transparency variable $\left(\mathrm{X}_{1}\right)$, it is known that total number of the respondents $(\mathrm{N})$ was 83 . The total minimum value (Min) of the respondents' answers on the transparency variable $\left(\mathrm{X}_{1}\right)$ was equal to 34 , the total maximum value (Max) was 45, and the total value of the total answer (Sum) was 3311. The mean or average value of the minimum and maximum values was 39.89 with a standard deviation of 3.361 .

In the accountability variable $\left(\mathrm{X}_{2}\right)$, the number of respondents $(\mathrm{N})$ was 83 . The total minimum value (Min) of the respondents' answers was 60 , and the maximum total value (Max) was 75 , with a total overall score of 5,482 . The mean value in the accountability variable $\left(\mathrm{X}_{2}\right)$ was 66.05 with a standard deviation of 5.704 .

Table 3. Heteroscedasticity Test

\begin{tabular}{lccc}
\hline \multicolumn{4}{c}{ Coefficients $^{\mathrm{a}}$} \\
\hline Model & \multicolumn{3}{c}{ Collinearity Statistics } \\
\hline (Constant) & .404 & Tolerance & VIF \\
Transparency & .232 & .332 & 3.010 \\
Accountability & .188 & .332 & 3.010 \\
\hline a. Dependent Variable: RES_2 & &
\end{tabular}

Table 4. Result of the t Test

\begin{tabular}{llll}
\hline \multicolumn{4}{c}{ Coefficients $^{\mathrm{a}}$} \\
\hline Model & \multicolumn{1}{c}{$\mathrm{t}$} & Sig. \\
\hline 1 & (Constant) & & \\
& Transparency & .332 & 3.010 \\
& Accountability & .332 & 3.010 \\
\hline
\end{tabular}

a. Dependent Variable: Village Financial Management

Table 5. F Test Result

\begin{tabular}{llcl}
\hline \multicolumn{3}{c}{ ANOVA $^{\mathrm{a}}$} \\
\hline Model & & df & Sig. \\
\hline 1 & Regression & 2 & $.000^{\mathrm{b}}$ \\
& Residual & 80 & \\
& Total & 82 & \\
\hline
\end{tabular}

a. Dependent Variable: Village Financial Management

b. Predictors: (Constant), Accountability, Transparency

Table 6. Determination coefficient test result

\begin{tabular}{lcc}
\hline \multicolumn{3}{c}{ Model Summary } \\
\hline Model & $\mathrm{R}$ & R Square \\
\hline 1 & $.607^{\text {a }}$ & .368 \\
\hline a. Predictors: (Constant), Accountability, Transparency
\end{tabular}




\begin{tabular}{lcccccc}
\hline & \multicolumn{3}{c}{ Descriptive Statistics } & & \\
\hline & $\mathrm{N}$ & Min & Max & Sum & Mean & Std. Deviation \\
Transparency & 83 & 34 & 45 & 3311 & 39.89 & 3.361 \\
Accountability & 83 & 60 & 75 & 5482 & 66.05 & 5.704 \\
Village Financial Management & 83 & 72 & 90 & 6622 & 79.78 & 6.905 \\
Valid N (listwise) & 83 & & & & & \\
\hline
\end{tabular}

In the village financial management variable $(\mathrm{Y})$, it is known that the number of the respondents $(\mathrm{N})$ was 83 . The total minimum value (Min) of the respondents' answers was 72, and the total maximum value (Max) was 90 , with the total number of respondents' answers of 6622. The mean value at village financial management variable (Y) was 79.78 with a standard deviation of 6.905 .

Based on the results of data processing analyses, the $\mathrm{t}_{\text {-count }}$ was $<\mathrm{t}_{\text {-table }}(0.481<1.99006)$, indicating that $\mathrm{H} 1$ was rejected, and $t_{\text {-count }}$ was $>t_{\text {-table }}(3.533>1.99006)$, indicating that $\mathrm{H} 2$ was accepted. Because of this, in this study, partial transparency did not affect the village financial management. The negative result of the transparency variable testing was in the dimensions of disclosure and disclosure. Accountability partially effectd the village financial management; furthermore, the result of the $\mathrm{F}$ test indicates that $\mathrm{F}_{- \text {count }}$ was $>\mathrm{F}_{-}$ table $(23.308>3.109)$, which means transparency and accountability have a simultaneous effect on the village financial management.

The result of the study on the transparency variable was in line with the result of the research conducted by Sukmawati and Nufitriani (2019) whose research results show that transparency does not affect the village financial management in 30 village governments in Garut Regency. This research on the accountability variable was in line with Kisnawati et.al (2017), Umami and Nurodin (2017), Rizal et.al (2018), Sangki (2017), Putra et al. (2017), Wawansyah (2019) and Wafirotin and Septiviastuti (2019) whose research results show that accountability effects the village financial management.

\section{Managerial Implication}

According to Marota and Alipudin (2019) and Marota et.al (2020), the village officials are the main pillars in the supply chain monitoring system of village funding, from the planning, implementation, and accountability stages as a pillar of good village governance. Thus, village government consist of village head, village secretary, and other village officials would be responsible for village financial management due to its transparency and accountability.

\section{CONCLUSIONS AND RECOMMENDATION}

\section{Conclusions}

Based on the results of the data processing test, it is known that $\mathrm{t}_{\text {count }}$ was $<\mathrm{t}_{\text {table }}(0.481<1.99006)$ which means $\mathrm{H}_{1}$ was rejected. Based on this, transparency does not affect the village financial management. This result shows the importance of deep communication between village officials and their communities for transparency purposes, as well as the communication in marketing (Lisarini et.al, 2018).

Based on the results of the data processing test, the $\mathrm{t}_{\text {count }}$ was $>\mathrm{t}_{\text {table }}(3.533>1.99006)$, indicating that $\mathrm{H}_{2}$ was accepted. Based on this, accountability affects the village finance management. These results are in line with research conducted by Umami and Nurodin (2017) and Andriani (2019).

Based on the results of the data processing test, the $\mathrm{F}_{\text {count }}$ was $>\mathrm{F}_{\text {table }}(23.308>3.109)$, indicating that $\mathrm{H}_{3}$ was accepted, thus transparency and accountability have a simultaneous effect on village financial management. In addition, based on the coefficient of determination test, it is known that transparency and accountability have a significant effect $(36.8 \%)$ on village financial management, and the remaining $63.2 \%$ was affected by other factors outside the studied variables.

\section{Recommendations}

For academic advice this research is expected to be a forum for problem solving regarding village financial management that is managed effectively, efficiently, 
and supported by budgetary discipline, and to apply the principles of transparency and accountability so that good financial management and increased public confidence in the village government are created. This research is expected to contribute to the development of accounting science, especially Public Sector Accounting regarding the Effect of Transparency and Accountability on Village Financial Management.

Practical advice for village officials openness and disclosure are more maximized by utilizing technology or social media, improvement in relations with the community so that the community can maximally involve in the village development, and increase in the accuracy to determine the policy and use of village finances as accurately as possible so that the village finances can be managed effectively and efficiently, and to achieve the village goals as stated in the Village Budget and Expenditure.

Practical advice for village consultative body this body needs to be further improved in terms of accommodating the aspirations of the community in village development in favour of the interests of the community, and this unit should be more critical in overseeing the performance of village governments, especially in terms of transparency and accountability.

\section{ACKNOWLEDGEMENT}

This research and publication were funded by Ministry of Research and Technology/National Research and Innovation Agency based on letter No. 8/E1/KPT/2020 and contract No. 080/SP2H/LT/DRPM/2020 and No. 014/SP2HL/LT-MONO/LL4/PP/2020 and No. 24.1/ LPPM-UP/KP-PDP/IV/2020

\section{REFERENCES}

Andriani M. 2019. Pengaruh transparansi, akuntabilitas, dan partisipasi masyarakat terhadap pengelolaan dana desa (studi pada Desa Luk, Kecamatan Rhee, Kabupaten Sumbawa). Jurnal of accounting, Finance, and Auditing 1(2): 1-13. https://doi.org/10.37673/jafa.v1i2.323.

Faridah, SuryonoB.2015.Transparansidanakuntabilitas pemerintahan desa dalam pengelolaan Anggaran Pendapatan dan Belanja Desa (APBDes). Jurnal Ilmu dan Riset Akuntansi 4(5):1-20.

Hendratmi H, Mulyadi, Widiastuti R. 2017. Pengaruh transparansi dan komitmen terhadap akuntabilitas pengelolaan anggaran. Jurnal Ilmiah Akuntansi Fakultas Ekonom 2(3): 78-79. https://doi. org/10.34204/jiafe.v3i2.767.

Kisnawati B, Astini Y, Oktaviani N. 2018. Transparansi dan Akuntabilitas Pengelolaan Keuangan Alokasi Dana Desa (ADD) di Kecamatan Moyo Hilir Kabupaten Sumbawa Besar. Jurnal Valid 15(1): 1-10.

Lisarini E, Yusuf E, Sutina S. 2018. The effect of quality, communication and outputs of marketing channel of cianjur pandanwangi rice on consumer trust in java west marketing area. Indonesian Journal of Business and Entrepreneurship (IJBE) 4(2): 109-121. https://doi.org/10.17358/ijbe.4.2.109.

Mardiasmo. 2018. Akuntansi Sektor Publik Edisi Terbaru. Yogyakarta: Penerbit Andi.

Marota R, Alipudin A. 2019. Faktor-faktor yang mempengaruhi sistem pengawasan keuangan desa (Studi Kasus Wilayah Kabupaten Bogor). Jurnal Ilmiah Akuntansi Fakultas Ekonomi 5(1): 1-10. https://doi.org/10.34204/jiafe.v5i1.1409.

Marota R, Alipudin A. 2019. Monitoringsystem on village fund: synergy between communities and regulators (case study on bogor district government). Journal of Humanities and Social Studies 3(2): 54-59. https://doi.org/10.33751/ jhss.v3i2.1456.

Marota R, Mulyani S, Sukmadilaga C, Kamilah ZNA and Mauludina MA. 2020. Ruralfund supply chain monitoring system: evidence from indonesia and lesson experiences from South Korea and Malaysia. International Journal of Supply Chain Management 9(2): 11-17.

Meutia I, Liliana. 2017. Pengelolaan Keuangan Desa. Jurnal Akuntansi Multiparadigma 8(2): 336-352. https://doi.org/10.18202/jamal.2017.08.7058.

Putra IPAS, Sinarwati K, Wahyuni MA. 2017. Akuntabilitas dan transparansi pengelolaan Alokasi Dana Desa (ADD) di Desa Bubunan Kecamatan Seririt Kabupaten Buleleng. E-Journal S1 Akuntansi Universitas Pendidikan Ganesha 8(2): 1-11. https://doi.org/10.22219/ jaa.v1i1.6939.

Ramadanis, Ahyaruddin M. 2019. Akuntabilitas dan transparansi pengelolaan Anggaran Pendapatan dan Belanja Desa (APBDes). Jurnal Akuntansi dan Ekonomika 9(1): 111-118. https://doi. org/10.37673/jafa.v1i1.188.

Rizal, Fitri A, Rantika D. 2018. Akuntabilitas dan Transparansi Pengelolaan Anggaran Pendapatan 
dan Belanja Desa (APBDesa) Tahun 2016. Jurnal Al-Iqtishad 14(1): 20-37. https://doi. org/10.24014/jiq.v14i01.5457.

Sangki A, Gosal R, Kairupan J. 2017. Penerapan Prinsip Transparansi dan Akuntabilitas Dalam Pengelolaan Anggaran Pendapatan dan Belanja Desa (Suatu Studi di Desa Tandu Kecamatan Lolak Kabupaten Mongondouw). Jurnal Eksekutif 1(1): 1-12.

Sugiyono. 2017. Statistika Untuk Penelitian. Bandung: Penerbit Alfabeta.

Sujarweni, W. 2015. Akuntansi Sektor Publik, teori, konsep, aplikasi. Yogyakarta: Pustaka Baru Press.

Sujarweni, W. 2014. Metodologi Penelitian (Lengkap, Praktis, dan Mudah dipahami). Yogyakarta: Pustaka Baru Press.

Sukmawati F, Nufitriani A. 2019. Pengaruh transparansi dan akuntabilitas terhadap pengelolaan keuangan desa (Studi Pada Pemerintah Kabupaten Garut). Jurnal Ilmiah Bisnis, Pasar Modal, dan UMKM 2(1): 52-66. https://doi.org/10.24014/jiq. v14i01.5436.
Soleh C, Rochansjah H. 2015. Pengelolaan Keuangan Desa (Edisi Revisi). Bandung: Fokusmedia.

Syafei M, Fahmi I, Hubeis AVS. 2016. Faktor-faktor yang mempengaruhi kinerja karyawan PT Pul Logistics Indonesia. Jurnal Aplikasi Bisnis dan Manajemen 2(3): 217-229. https://doi. org/10.17358/JABM.2.3.217.

Umami R, Nurodin I. 2017. Pengaruh transparansi dan akuntabilitas terhadap pengelolaan keuangan desa. Jurnal Ilmiah Ilmu Ekonomi 6(11): 74-80.

Wafirotin KZ, Septiviastuti U. 2019. The effect of transparency, community participation, and accountability on management of village funds in Ponorogo Regency. Jurnal Ilmiah Ilmu Ekonomi 14(1): 31-44. https://doi.org/10.24269/ ekuilibrium.v14i1.1527.

Wawansyah C. 2019. Akuntabilitas pengelolaan Anggaran Pendapatan dan Belanja Desa (APBDes) 2017 di Desa Poto. Jurnal Of Accounting, Finance and Auditing 1(1): 1-9. https://doi.org/10.37673/jafa.v1i1.188. 